This document was prepared in conjunction with work accomplished under Contract No. DE-AC09-96SR18500 with the U. S. Department of Energy.

\title{
DISCLAIMER
}

This report was prepared as an account of work sponsored by an agency of the United States Government. Neither the United States Government nor any agency thereof, nor any of their employees, nor any of their contractors, subcontractors or their employees, makes any warranty, express or implied, or assumes any legal liability or responsibility for the accuracy, completeness, or any third party's use or the results of such use of any information, apparatus, product, or process disclosed, or represents that its use would not infringe privately owned rights. Reference herein to any specific commercial product, process, or service by trade name, trademark, manufacturer, or otherwise, does not necessarily constitute or imply its endorsement, recommendation, or favoring by the United States Government or any agency thereof or its contractors or subcontractors. The views and opinions of authors expressed herein do not necessarily state or reflect those of the United States Government or any agency thereof. 
WSRC-RP-2005-01625

Revision 0

Key Words: supernate

alkaline

HLW

\section{Task Technical and Quality Assurance Plan for Determining Uranium and Plutonium Solubility in Actual Tank Waste Supernates}

William D. King

SRNL Waste Processing Technology

Publication Date: June 28, 2005 


\section{INTRODUCTION}

Savannah River Site tank waste supernates contain small quantities of dissolved uranium and plutonium. Due to the large volume of supernates, significant quantities of dissolved uranium and plutonium are managed as part of waste transfers, evaporation and pretreatment at the Savannah River Site in tank farm operations, the Actinide Removal Project (ARP), and the Salt Waste Processing Facility (SWPF). Previous SRNL studies have investigated the effect of temperature and major supernate components on the solubility of uranium and plutonium. ${ }^{1-3}$ Based on these studies, equations were developed for the prediction of $U$ and $\mathrm{Pu}$ solubility in tank waste supernates. The majority of the previous tests were conducted with simulated waste solutions. The current testing is intended to determine solubility in actual tank waste samples (asreceived, diluted, and combinations of tank samples) as a function of composition and temperature. Results will be used to validate and build on the existing solubility equations.

Solubility testing will involve the measurement of $\mathrm{U}$ and $\mathrm{Pu}$ concentrations for solutions in contact with precipitated uranium and plutonium solid phases. When the system is at equilibrium, the solution is saturated in the component of interest and the concentration no longer changes with time. It is crucial that the solution of interest be equilibrated with a representative solid phase. Compositional differences may exist for solids formed from different waste supernates. For the highly basic solution chemistries exhibited by SRS high-level waste supernates, sodium diuranate, $\mathrm{Na}_{2} \mathrm{U}_{2} \mathrm{O}_{7}$, is believed to be the dominant solid phase of uranium formed. Dissolved uranium species are likely anionic, hydroxy and carbonato complexes such as $\mathrm{UO}_{2}(\mathrm{OH})_{4}{ }^{2-}$ and $\mathrm{UO}_{2}\left(\mathrm{CO}_{3}\right)(\mathrm{OH})_{2}{ }^{2-}$. The exact species in solution will depend on the concentrations of major solution components such as hydroxide, carbonate, nitrate, etc. It is expected that $\mathrm{PuO}_{2} \cdot \mathrm{HH}_{2} \mathrm{O}$ will be a dominant component of the plutonium solids formed.

Uranium and plutonium concentrations are frequently measured in tank supernate samples. Historically researchers used kinetic phosphorescence (ChemChek), emission spectroscopy, or thermal ionization mass spectrometry to determine uranium. In the last 10 years, inductively coupled plasma mass spectrometry (ICP-MS) has become the leading method at SRNL for the determination of uranium solution concentrations. Plutonium analysis will be conducted by ICP-MS or alpha pulse height counting using the Pu TTA method. Supernate samples from High Level Waste (HLW) tanks frequently contain suspended insoluble solids that may include significant quantities of uranium and plutonium. In some previous studies at SRNL, researchers filtered the as-received samples and measured the $\mathrm{U}$ and $\mathrm{Pu}$ concentrations in the resulting filtrate. A more common practice has been to analyze the as-received supernate samples including any insoluble solids. Thus, the measured concentrations may include contributions from both dissolved and insoluble species.

Testing conducted in support of SRS evaporator operations has established that solutions supersaturated in uranium can persist for days and weeks. ${ }^{4}$ Persistent supersaturation may arise from the fact that uranium speciation is complex and solid formation may 
result from the transfer of a species present at low concentration. ${ }^{5}$ For this reason, confirmation of equilibrium over extended time periods is important in the solubility determinations. Sample temperature changes could lead to supersaturation. Common practice for sampling and analyzing supernate samples does not include protocols for maintaining samples at the temperature of the tank from which the sample was taken. Since uranium and plutonium solubility are affected by temperature, the reported concentrations, typically measured at ambient laboratory temperature, may not reflect those in the tank at some elevated temperature. As a result, tests will be conducted to evaluate temperature effects on solubility and samples supersaturated in uranium or plutonium will be identified.

A formal validation of the prediction equations for uranium and plutonium solubility with actual tank waste solutions has not occurred. This task will develop analysis methods for $\mathrm{U}$ and Pu in tank supernate samples, measure the concentrations of these species in actual waste, determine $\mathrm{U}$ and $\mathrm{Pu}$ solubility, and compare the measured and predicted solubilities. This work will determine the accuracy of the prediction equations, and the data will be utilized to improve/correct the equations, if discrepancies are observed.

\section{TASK DESCRIPTION}

Technical Task Request HLE-TTR-2003-088 specifies that SRNL perform the following tasks:

1. Develop uranium analysis methods that differentiate soluble uranium from total uranium (includes dissolved and undissolved uranium) using four different tank supernate samples.

2. Measure total and dissolved uranium concentrations in an additional six selected tank supernate samples.

3. Determine the uranium solubility in all of the tank supernate samples and compare with that predicted.

4. Expand the uranium solubility prediction equation to include the effect of additional solution components (e.g., silicate and phosphate) and a wider range of temperatures.

Results from Task 4 have already been reported. ${ }^{6}$ This work is being tracked based on a New Information (NI\# 221-3135) document issued by the Closure Business Unit. The customer has also requested that the scope of this work be broadened to include plutonium solubility determination. Plutonium solubility data will build upon testing already conducted and predictive equations developed as part of an Independent Directed Research (IRD) Project at SRNL. ${ }^{1,3}$ This task plan is also intended to cover completion of the IRD project which evaluated plutonium and americium solubility with simulated waste solutions.

In addition to the tasks described above, the current testing will include: 1) characterization of as-received, diluted, and mixed actual waste samples, 2) solubility testing of diluted and mixed waste samples to provide a more complete range of chemical 
compositions for statistical analysis, 3) determination of temperature effects on solubility, and 4) characterization of solid phases formed. Current plans involve the use of three archive and five new tank samples, rather than the numbers specified in the original Technical Task Request.

\section{OVERVIEW OF EXPERIMENTAL METHODOLOGY}

Note: The tasks below are similar but not identical to the tasks outlined in the Technical Task Request.

Task 1 - Analytical Method and Test Protocol Development Researchers will develop an analytical protocol for measuring dissolved and total $\mathrm{U}$ and $\mathrm{Pu}$ in tank supernate samples using archived samples in SRNL. Consideration will be given to the filter membrane material and pore size, filtration temperature, and sample stabilization method (e.g., acidification with nitric acid). For the development of the total $\mathrm{U} / \mathrm{Pu}$ analysis protocols, sub-sampling techniques will be considered that ensure representative sampling of the undissolved solids and the method for dissolving solids.

Testing will be conducted approaching saturation from both supersaturated and unsaturated conditions. This method was previously demonstrated by Addai-Mensah. ${ }^{6}$ Supersaturated conditions will be obtained by the addition of very small volumes of acid solutions containing dissolved uranium and/or plutonium at levels that greatly exceed solubility in the supernate. This will result in rapid bulk precipitation of $U$ and Pu solids. It is expected that equilibrium conditions will be observed within hours of precipitation, since a large excess of ideal nucleation sites for solids formation will be present. However, given the tendency to form stable supersaturated solutions, it will be necessary to confirm that true equilibrium conditions have been obtained by continued observation and analysis (at least for selected samples). This method has been used in previous uranium and plutonium solubility tests at SRNL. The solids formed by this method should be somewhat representative of those solids that might form in actual SRS processing conditions. (It should be noted, however, that the composition of the solids could vary slightly with the rate of formation, since several equilibria involving a number of species may be involved.)

If possible, these solids will be isolated, characterized (in some cases), and used for dissolution tests with a fresh supernate sample. This method represents the ideal way to approach saturation from unsaturated conditions, since representative solids have been obtained directly from the test solutions of interest. Of course, in order to use this method, sufficient solids must be generated from each test sample. This method may not be practical if sufficient sample test volumes are not available, or if the method generates too many samples given the available budget. In the event that the above method for solids generation is impractical, other synthesis methods will be developed for the generation of sufficient masses of $\mathrm{U}$ and Pu solids for solubility testing. If possible, uranium and plutonium solubility testing will be conducted simultaneously as a cost savings. Limited testing may be necessary to validate this approach. 
Some portions of this work may be carried out using simulated supernate solutions in radiohoods located in WPT laboratories. However, the bulk of this task will be conducted with tank supernates in the Shielded Cells facility at SRNL. ICP-MS will serve as the primary analytical method for uranium and plutonium, although confirmatory analysis may be conducted by Pu TTA, particularly if plutonium concentrations are near ICP-MS detection limits. Ion chromatography will be used to measure the concentrations of major anions exclusive of hydroxide, aluminate and carbonate, which will be determined by titration methods. Replicate samples, blanks and control samples will be submitted for all analyses.

\section{Task 2 - Analysis of Tank Supernate Samples}

Researchers will analyze the tank supernate samples using the analytical protocols developed in Task 1. The tank samples were selected so as to include both F and H-Area waste tanks, evaporator feed tanks, non-evaporator feed tanks that have had waste transfers within six months, and tanks that have had no waste transfers for over two years. Consideration was given to include tanks that are scheduled to be sampled for corrosion chemistry whenever possible. This task will be carried out in the Shielded Cells facility at SRNL. ICP-MS will serve as the primary uranium and plutonium determination methods. Ion chromatography will be used to measure the concentrations of major anions exclusive of hydroxide, aluminate and carbonate, which will be determined by titration methods. The anion concentrations are needed for calculating uranium solubilities in Task 4. Replicate samples, blanks and control samples will be submitted for all analyses.

Task 3 - Determine U/Pu Solubility in Tank Samples

Uranium and plutonium solubilities will be measured for each tank sample by adding excess uranyl and plutonium (IV) nitrate (nitric acid matrix) solutions, respectively. As mentioned above, uranium and plutonium solubility may be determined simultaneously, depending upon the results of Task 2. Supernate samples will be filtered and analyzed for U/Pu content after various time periods. Samples will be collected until agreement is observed between three consecutive analyses, indicating that equilibrium has been obtained between the solid and liquid phases. ICP-MS will serve as the primary analysis method. Replicate samples, blanks and control samples will be submitted for all analyses.

Solids isolated from selected solubility tests will be isolated and analyzed by various methods including Energy Dispersive Spectroscopy (EDS) and X-Ray Diffraction (XRD) to determine the elemental composition and phase of the solid material. The solids may also be used to conduct solubility tests by dissolution into fresh supernate samples. This allows for determination of the $\mathrm{U}$ and $\mathrm{Pu}$ saturation points by two separate methods. Confirmatory information is particularly important in this case, since supersaturation has been observed and this is not a simple system involving a single component, but likely involves interconversion between numerous species. In the event that sufficient solids cannot be obtained by bulk precipitation from each test sample, an alternative solid synthesis method will be utilized. 
Temperature will be varied for selected samples as part of this task.

Task 4 - Compare Observed versus Predicted U/Pu Solubilities

Predicted uranium and plutonium maximum concentrations for each supernate sample will be computed using the equations mentioned previously. The predicted and measured concentrations will be compared. If the predicted and measured values are inconsistent, WPT will make recommendations on a path forward to modify and improve the prediction equations.

Task 5 - Generate New Samples and Conduct Additional Solubilty Tests As Needed Depending upon the results of Task 4, additional samples will be generated by dilution and mixing and/or additional tests will be conducted at different temperatures to significantly improve the $95 \%$ confidence limits for the model predictions. A statistical sample test matrix will be developed based on the existing data and predictive equations in order to provide the best dataset for model validation. Variable parameters within the matrix will be chemical composition and temperature. New sample compositions generated by dilution or mixing will require additional analysis as described in Task 2 .

Task 6 - Americium and Plutonium Solubility Testing, Completion of Previous Testing This task will complete sampling and analysis of tests with simulated supernate solutions initiated in the IRD study on americium and plutonium solubility. ${ }^{3}$ This testing expands the composition range for plutonium and provides the first experiments for testing americium solubility over a range of alkaline salt solutions and temperature.

This set of samples will also determine the influence of filter membrane pore size (0.02 $0.45 \mu \mathrm{m}$ ), if any, on the americium and plutonium concentration. The results from this last set of samples will be combined with previous analytical results and analyzed to determine predictive solubility models for americium and plutonium. T. B. Edwards of the Statistical Consulting Section will perform the data analysis and develop predictive solubility equations. The results will be reported in a technical report updating the preliminary results reported earlier. ${ }^{3}$

This task will be conducted separately from Tasks 1-5.

\section{DELIVERABLES AND ACCEPTANCE}

The deliverables include written or oral reports (as requested) and a final report incorporating the results. Reports will include a design check per WSRC Manual E7, Procedure 2.40. ${ }^{7}$ The final reports will receive approval from selected CSTE personnel.

\section{RESPONSIBILITIES}

Personnel in the Waste Processing Technology Section (WPTS) will plan and direct the task activities and interpret and document results and conclusions. SRNL WPTS 
researcher William D. King will serve as the technical lead for Tasks 1-5. SRNL WPTS researcher David T. Hobbs will serve as the technical lead for Task 6. Tommy B. Edwards from SRNL Statistical Consulting will provide solubility predictions using the current models and will update the model equations as needed based on the data obtained with the actual waste samples and the simulated samples from the IRD study. Personnel in the SRNL Analytical Development Section will provide analytical services for the sample characterization. SRNL Shielded Cells Operations (SCO) personnel will receive the tank samples and provide technicians trained in the use of manipulators for remote handling and testing of radioactive materials. Personnel from SRNL QAD will review and approve the Technical Quality Assurance Plan and provide guidance and oversight for this task.

\section{DOCUMENTATION}

All pertinent instructions, results and calculations will be recorded in a numbered notebook in accordance with Manual L1, SRNL Procedures Manual, Procedure 7.16. ${ }^{7}$ A laboratory notebook will provide lifetime storage as a record. ${ }^{8}$ Drafts of all preliminary reports will receive review by selected WPTS and HLW personnel. Final reports will be issued after comment resolution.

\section{SCHEDULE}

The schedule for this task will be reviewed weekly at the SRNL Closure Business Unit (CBU) Plan of the Week meeting at SRNL.

\section{RISK REVIEW}

Table IV depicts the programmatic risks associated with this task and the associated mitigation, where identified.

Table IV: Programmatic Risk and Mitigation

\begin{tabular}{|c|c|c|}
\hline Risk Factor & Event & Consequences/Mitigation \\
\hline equipment & failure & short program delays \\
\hline analytical support & instrument failure & short program delays \\
\hline personnel & illness/vacation & $\begin{array}{c}\text { primary and secondary researchers and } \\
\text { analysts identified }\end{array}$ \\
\hline facility (electrical/ventilation) & outage & short delays \\
\hline
\end{tabular}

\section{SAFETY}

The author has completed the R \& D safety checklist as described in the conduct of R \& D Manual $^{9}$ which is provided as Attachment 2 of this report. 


\section{QUALITY ASSURANCE}

\section{Task Quality Assurance Checklist}

See Attachment 1.

\section{Conduct of Research and Development Checklist}

See Attachment 2.

\section{Documents Requiring Customer Approval}

The following documents require customer approval:

- Task Technical and Task Quality Assurance Plan

- $\quad$ Final Report

\section{RECORDS}

The following items shall be designated as records for this experimental program:

- controlled laboratory notebook(s)

- final report

- supporting documentation as determined by the task leader 


\section{REFERENCES}

1. D. T. Hobbs, T. B. Edwards, and S. D. Fleischman, "Solubility of Plutonium and Uranium in Alkaline Salt Solutions (U)”, WSRC-TR-93-056, February 12, 1993.

2. D. T. Hobbs and T. B. Edwards, "Solubility of Uranium in Alkaline Salt Solutions (U)”, WSRC-TR-93-454, March 29, 1994.

3. Rudisill, T. R.; Hobbs, D. T.; Edwards, T. B. "Preliminary Results from Plutonium/Americium Solubility Studies Using Simulated Savannah River Site Waste Solutions,” WSRC-TR-2004-00349, Rev. 0, July 2004.

4. R. A. Peterson and R. A. Pierce, "Sodium Diuranate and Sodium Aluminosilicate Precipitation Testing Results”, WSRC-TR-2000-00156, Rev. 0, May 15, 2000.

5. D. T. Hobbs and D. G. Karraker, "Recent Results on the Solubility of Uranium and Plutonium in Savannah River Site Waste Supernate”, Nuclear Technology, 114, 318 (1996).

6. J. Addai-Mensah, J. Lu, and M. Zbik, "Sodium Aluminosilicate and Uranate Solid Phases Behavior Studies in Support of HLW Processing”, Ian Wark Research Institute, University of South Australia, March 2004.

7. "Design Verification and Checking,” Manual E7, Procedure 2.40, Rev. 0, May 26, 1993.

8. Laboratory Notebooks and Logbooks,” Manual L1, Procedure 7.16, Rev. 2, April 16, 2003.

9. “Conduct of Research and Development," WSRC-IM-97-0024, Rev. 3, October 2004. 


\section{APPROVALS}

\section{Author}

$\frac{\text { William D. King }}{6 / 25 / 05}$

\section{Quality Assurance}

Steve Loflin, SRNL Quality Assurance Department $\frac{6128105}{\text { Date }}$

\section{Management}

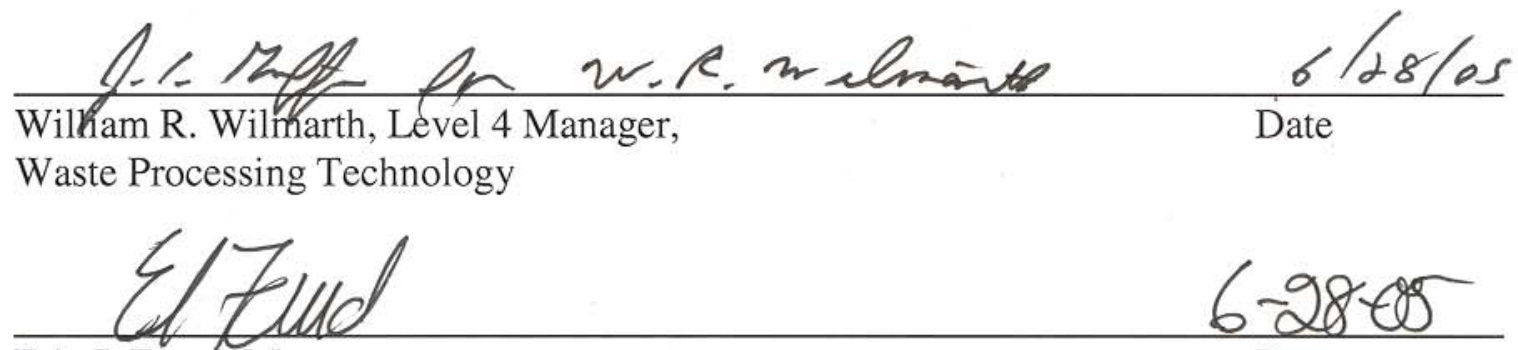

Eric J. Freed, Manager,

Date

Process Engineering, High-Level Waste Division

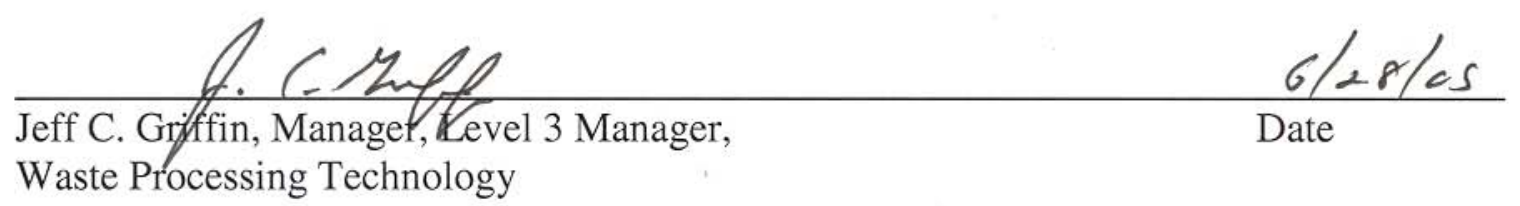




\section{Attachment 1. WPT QA Checklist}

\section{WPT TASK QUALITY ASSURANCE PLAN CHECKLIST}

Task Technical Plan No: WSRC-RP-2005-01625 Task Title: Determining Uranium and Plutonium Solubility in Actual Tank Waste Supernates

Listed below are the sections of WSRC QA Manual (1Q). Check the 1Q sections applicable to your task. Also, check procedures WPT implements to control the task. This checklist identifies controls for task activities performed by WPT only. (Form Revised 5/25/2005)

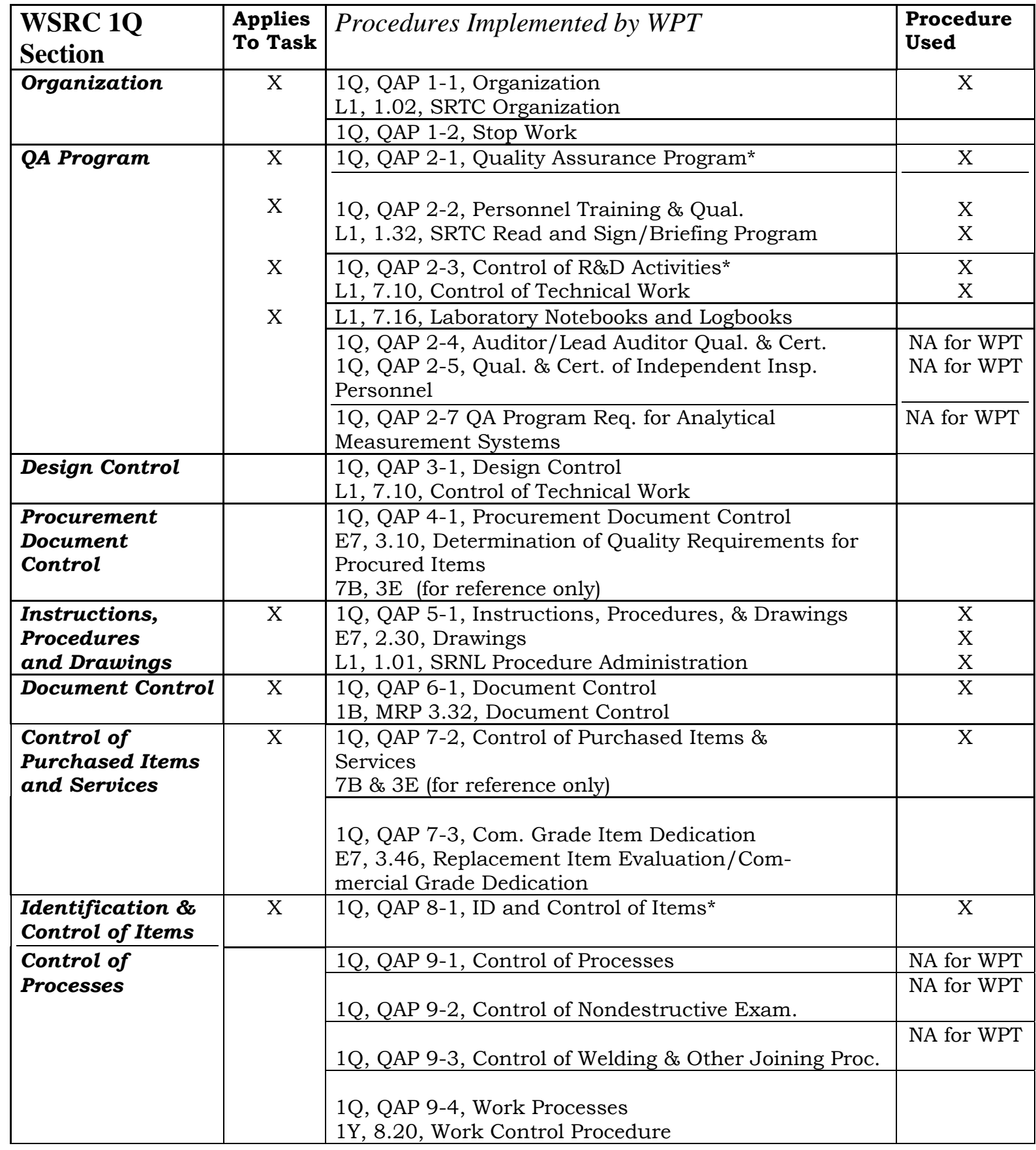




\begin{tabular}{|c|c|c|c|}
\hline Inspection & & $\begin{array}{l}\text { 1Q, QAP } 10-1, \text { Inspection } \\
\mathrm{L} 1,8.10, \text { Inspection }\end{array}$ & NA for WPT \\
\hline Test Control & & $\begin{array}{l}\text { 1Q, QAP } 11-1 \text {, Test Control (applies to WPT only for } \\
\text { acceptance testing; R\&D test activities are controlled } \\
\text { by } 1 \text { Q, QAP 2-3) }\end{array}$ & \\
\hline \multirow{3}{*}{$\begin{array}{l}\text { Control of } \\
\text { Measuring \& Test } \\
\text { Equipment }\end{array}$} & \multirow[t]{3}{*}{$\mathrm{X}$} & 1Q, QAP 12-1, Control of Measuring \& Test Equipment & $\mathrm{X}$ \\
\hline & & $\begin{array}{l}\text { 1Q, QAP 12-2, Control of Installed Process } \\
\text { Instrumentation }\end{array}$ & \\
\hline & & $\begin{array}{l}\text { 1Q, QAP 12-3, Control \& Calibration of Radiation } \\
\text { Monitoring Equipment }\end{array}$ & $\mathrm{X}$ \\
\hline $\begin{array}{l}\text { Packaging, } \\
\text { Handling, } \\
\text { Shipping \& } \\
\text { Storage }\end{array}$ & & 1Q, QAP 13-1, Pkg., Handling, Ship. \& Storage* & \\
\hline $\begin{array}{l}\text { Inspection, Test, } \\
\text { and } \\
\text { Operating Status }\end{array}$ & & 1Q, QAP 14-1, Inspection, Test, \& Operating Status* & \\
\hline $\begin{array}{l}\text { Control of } \\
\text { Nonconforming } \\
\text { Items \& Activities }\end{array}$ & $\mathrm{X}$ & 1Q, QAP 15-1, Control of Nonconforming Items* & $\mathrm{X}$ \\
\hline $\begin{array}{l}\text { Corrective Action } \\
\text { System }\end{array}$ & $\mathrm{X}$ & $\begin{array}{l}\text { 1Q, QAP 16-3 Corrective Action Program } \\
\text { 1.01, MP 5.35, Corrective Action Program }\end{array}$ & $\begin{array}{l}\mathrm{X} \\
\mathrm{X}\end{array}$ \\
\hline QA Records & $\mathrm{X}$ & $\begin{array}{l}\text { 1Q, QAP 17-1, QA Records Management* } \\
\text { L1, 7.16, Laboratory Notebooks and Logbooks }\end{array}$ & $\mathrm{X}$ \\
\hline \multirow[t]{5}{*}{ Audits } & \multirow[t]{5}{*}{$\mathrm{X}$} & 1Q, QAP 18-2, Surveillance & $\mathrm{X}$ \\
\hline & & 1Q, QAP 18-3, QA External Audits & \\
\hline & & $\begin{array}{l}\text { 1Q, QAP 18-4, Management Assessment Program } \\
\text { 12Q, Assessment Manual }\end{array}$ & \\
\hline & & 1Q, QAP 18-6, Quality Assurance Internal Audits & \\
\hline & & 1Q, QAP 18-7, Quality Assurance Supplier Surveillance & \\
\hline $\begin{array}{l}\text { Quality } \\
\text { Improvement }\end{array}$ & & 1Q, QAP 19-2, Quality Improvement* & \\
\hline $\begin{array}{l}\text { Software Quality } \\
\text { Assurance }\end{array}$ & & $\begin{array}{l}\text { 1Q, QAP 20-1, Software QA } \\
\text { L1, 8.20, Software Management \& QA }\end{array}$ & \\
\hline $\begin{array}{l}\text { Environmental } \\
\text { QA }\end{array}$ & & $\begin{array}{l}\text { 1Q, QAP 21-1, Quality Assurance Requirements for } \\
\text { the Collection and Eval. of Environmental Data }\end{array}$ & NA for WPT \\
\hline
\end{tabular}

EXCEPTIONS/ADDITIONS-PROCEDURES IDENTIFIED ON THE CHECKLIST WITH AN ASTERISK $(*)$ ARE SUPPLEMENTED BY A SRNL CLARIFICATION IN L1, 8.02, "SRTC QA PROGRAM CLARIFICATIONS". WSRC-IM2002-00011, “TECHNICAL REPORT DESIGN CHECK GUIDELINES,” WILL BE USED TO HELP ENSURE THE QUALITY AND CONSISTENCY OF THE TECHNICAL REVIEWER PROCESS FOR TECHNICAL REPORTS PRODUCED BY SRNL WASTE TREATMENT TECHNOLOGY. 
Attachment 2. R \& D Checklist

\section{Savannah River National Laboratory Conduct of Research and Development Hazards Screening Checklist}

Project/Task: Determining Uranium and Plutonium Solubility in Actual Tank Waste Supernates

Reviewer: William D. King Date: June 17, 2005

STEP 1. GENERAL HAZARD SCREENING

RADIOACTIVE MATERIALS

Does the activity involve:
A. Radioactive materials?
$\underline{X}$ YES
NO
B. Devices with internal radioactive sources?
$\square$ YES
$\underline{X}$ NO

If YES to either, then see Figures 6, 7, 8, 9, \& 12.

RADIATION-GENERATING INSTRUMENTS AND COMPONENTS

Does the activity involve:
A. Lasers"
YES
$\underline{X}$ NO
B. High intensity light, UV, IR, or near IR radiation?
YES
$\underline{X}$ NO
C. NMR or magnetic fields $>\mathbf{6 0 0}$ Gauss?
YES
$\mathrm{X}$ NO
D. Electromagnetic field generators?
$\square$ YES
$\underline{X}$ NO
E. Microwave generators?
$\square$ YES
$\underline{\mathrm{X}}$ NO
F. Electron guns or $\mathrm{x}$-ray tubes?
$\square$ YES
$\underline{X}$ NO

If YES to any, then see Figures 8 \& 12.

\section{CHEMICAL/HAZARDOUS MATERIALS}

Does the activity involve:
A. Corrosive, oxidizing, or reducing agents?
$\underline{X}$ YES
NO
B. Flammable or combustible substances?
$\square$ YES
$\underline{X}$ NO
C. Explosive or pyrophoric substances?
$\square$ YES
$\underline{\mathrm{X}}$ NO
D. Volatile solvents?
$\square$ YES
$\underline{X}$ NO

If YES to any, see Figures 8, 9, 10, \& 12.

E. Toxic substances?

$\begin{array}{ll}\square \text { YES } & \underline{X} \text { NO } \\ \underline{X} \text { YES } & \square \text { NO }\end{array}$

F. Carcinogens, mutagens, or teratogens?

(e.g., lead, asbestos, beryllium, and silica)

G. Biological agents?

$\square$ YES $\quad \underline{\mathbf{X}}$ NO

(e.g., microbes, viruses, bacteria, blood, or animal tissue)

If YES to any, then see Figures 8, 9, \& 12.

H. Cryogenic substances?

YES

$\underline{X}$ NO

If YES, then see Figures 8 \& 12. 


\section{HAZARDOUS ENERGIES}

Does the activity involve:

A. Exposed electrical conductors at $>50 \mathrm{~V}$ ?

YES $\underline{X}$ NO

If YES, then see Figure 13.

B. Temperatures $<0^{\circ} \mathrm{C}$ or $>40^{\circ} \mathrm{C}$ ?

$\underline{X}$ YES

NO

(e.g., furnaces,ovens, dryers, heaters, steam, dewars, chillers)

If YES, then see Figures 8, 10, \& 12.

C. Compressed gas cylinders?

D. Cryogenic gas cylinders?

E. Potential pressure differences $>\mathbf{1 5}$ psi?

(e.g., heated or cooled sealed containers; chemical reactions;

valve, regulator, or power failures; operator error; or fire scenerios)

F. Systems under vacuum or at a pressure between 0 and 15 psig?

(e.g., drums, sealed glove boxes, and vessels w/ diam. >6";

\section{YES \\ $\underline{\text { X NO }}$}

$\underline{X}$ NO

$\underline{X}$ NO

for standard lab use such as glass bottles or plastic containers)

If YES to any, then see Figures 5, 8, \& 12.

\section{ENVIRONMENTAL COMPLIANCE}

A. Is this a new activity?

B. If NO, then does the modified activity involve

$\underline{X}$ YES

a significant change in the:

- Type or amount of materials (e.g., chemicals, samples, or simulants) currently handled or released?

YES

NO

- Discharges of solids or liquids or gases?

$\square$ YES

NO

- Generation of hazardous , mixed, or rad waste?

YES

NO If YES to any, then see Figure 9.

\section{WORKSITE ENVIRONMENTAL CONDITIONS}

Does the activity involve:

A. Cold or heat stress conditions?

$\square$ YES $\quad \underline{\mathbf{X}}$ NO

B. Confined spaces, trenches, or excavations?

$\square$ YES

$\underline{\bar{x}}$ NO

C. Oxygen-deficient atmospheres (O2 < 19.5\%)

$\square$ YES

$\underline{\mathrm{X}}$ NO

D. Toxic atmospheres?

YES

$\underline{\mathrm{X}}$ NO

(e.g., airborne contaminate conc. 50\% of TLV, PEL, or other appropriate limit)

E. High noise levels (>85 dB)?

F. Exposed moving mechanical equipment?

(e.g., belts, gears, rollers, pulleys, shafts, blades, springs) 
G. Boating or work over water?

$$
\text { YES } \underline{\mathrm{X}} \text { NO }
$$

If YES to any, then see Figures 8 \& 10.

H. Field work ?

YES

X NO

(e.g., outdoor monitoring, installations, measurements, or observations)

If yes, then see Figures 8 \& 11.

I. Flammable atmospheres ( $>10 \%$ of the LEL)?

YES

$\underline{\mathrm{X}}$ NO

J. Open flames or sparks?

YES

$\underline{\mathrm{X}} \mathrm{NO}$

If YES to any, then see Figures 8, 10, \& 12.

K. Airborne mists, dusts, or vapors?

If YES, then see Figures 8, 9, \&10.

YES $\quad \underline{X}$ NO

L. Known or suspected hazardous waste site?

YES

$\underline{X}$ NO

If YES, then see Figures 7, 8, \& 9.

M. Gloveboxes or work in Shielded or Intermediate Cells?

\section{$\underline{X}$ YES}

If YES, then see Figure 4.

N. Work performed in SRNL?

$\underline{X}$ YES

NO

If YES, then see Figure 6.

O. Work performed in 774-A, 735-11A, 736-A, 749-A,

Mobil Lab, 735-A, or 786-A?

YES $\underline{X}$ NO

If YES, then see Figure 11.

\section{STEP 2. HAZARD MITIGATION AND CONTROL}

A. Complete the supporting flowcharts for the hazards identified In Step 1.

$$
\underline{\text { X Complete }}
$$

B. If the activity involves the onsite transfer or offsite shipment of hazardous substances (e.g., rad, flammable, corrosive, explosive,

or oxidizing material),
Then contact the SRNL Transportation Coordinator.

C. If reportable or accountable quantities of special nuclear materials

Or D2 are handled in any way, $\square$ YES

$\underline{X}$ NO Then contact the SRNL MC\&A MBA Custodian.

D. If the activity involves the installation of experimental R\&D equipment or systems,

$\square$ YES

$\underline{\mathrm{X}}$ NO Then complete Figure 13. 
E. If the activity involves the modification of the experimental R\&D equipment or systems, $\quad \square$ YES $\quad \underline{X}$ NO [Note: Like-for-like replacement of components is not considered a modification.]

Then complete Figure 13.

F. If the activity involves the maintenance of experimental R\&D

Equipment or systems,

$\square$ YES $\quad \underline{X}$ NO

Then complete Figure 13.

G. If the activity involves a pilot-scale process.

$\square$ YES $\quad \underline{\mathbf{X}}$ NO

Then complete Figure 14.

H. If a JHA has not been performed for the tasks associated with this Activity

$\square$ YES

$\underline{X}$ NO Then complete Figure 15. 